Ambiente \& Água - An Interdisciplinary Journal of Applied Science
ISSN 1980-993X - doi:10.4136/1980-993X
www.ambi-agua.net
E-mail: ambi.agua@gmail.com

\title{
Sanitary quality of the rivers in the Communities of Manguinhos' Territory, Rio de Janeiro, RJ
}

\author{
ARTICLES doi:10.4136/ambi-agua.2125
}

Received: 21 Apr. 2017; Accepted: 18 Dec. 2017

\author{
Natasha Berendonk Handam ${ }^{*}$; José Augusto Albuquerque dos Santos²; \\ Antonio Henrique Almeida de Moraes Neto ${ }^{3}$; Antonio Nascimento Duarte ${ }^{4}$; \\ Elizabeth Brito da Silva Alves ${ }^{4}$; Maria José Salles ${ }^{5}$; Adriana Sotero-Martins ${ }^{5}$

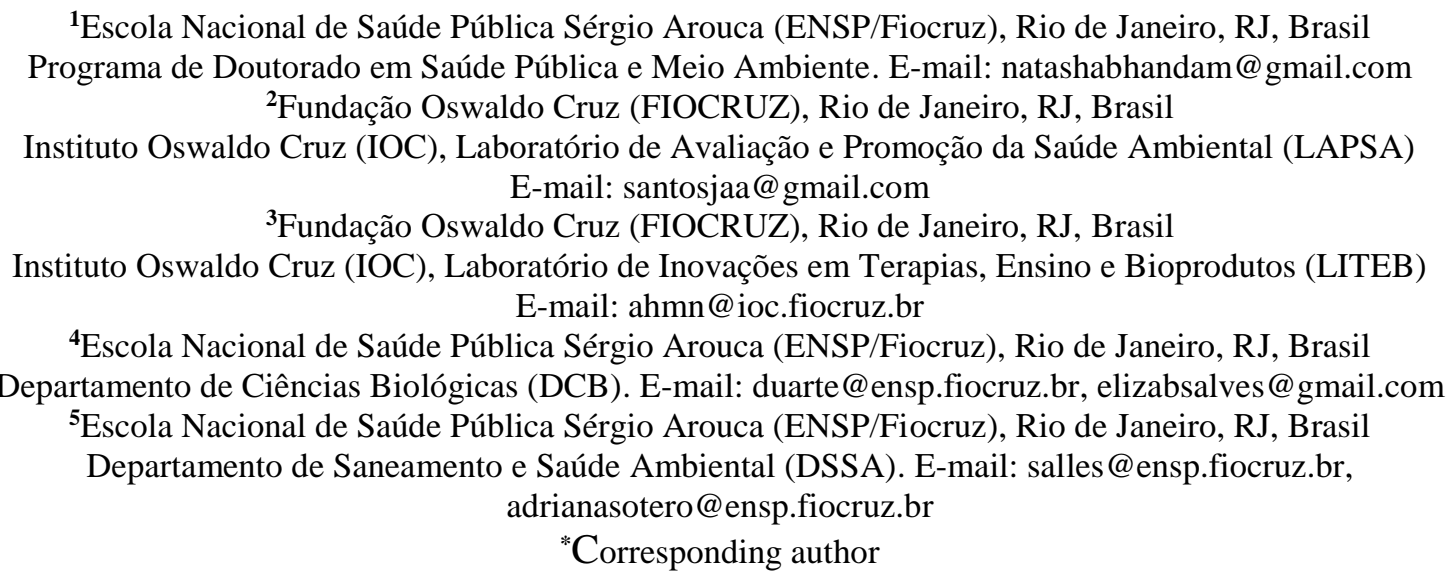

\begin{abstract}
Sanitation actions are rare in the communities of Manguinhos, so evaluation of the sanitary conditions of the river waters and the peridomestic soils of the communities allows the diagnosis of the risk of contamination. This study evaluated coliform levels (total coliforms and Escherichia coli) by the filter membrane method, and parasitological (by adapted Lutz and Baermann-Moraes methods) in the waters and soils of the Faria-Timbó, Jacaré and Canal do Cunha Rivers that pass through the communities of the Territory of Manguinhos, RJ, according to the standards established in Brazilian legislation. In all points of the rivers, the water was unfit, with an average level of Escherichia coli 3,800 times higher than that standardized in CONAMA Resolution No. 274/2000. Larvae, helminths eggs and protozoan oocysts were observed. Soil samples were also unfit, with mean total coliform level 77,000 times higher than that considered acceptable by SMAC Resolution 468/2010. The Escherichia coli average level was 53,000 times higher than that permitted by the legislation. However, helminths eggs were found in only one soil sample. It was concluded that the lack of sanitation in this locality results in the high coliform and parasitological levels of the river waters and in the peridomestic soils, and that immediate modifications are needed to the Brazilian environmental paradigm, which uses its water bodies as sewage disposal ditches.
\end{abstract}

Keywords: coliforms, parasites, peridomestic soil, river water, sanitary quality.

This is an Open Access article distributed under the terms of the Creative Commons Attribution License, which permits unrestricted use, distribution, and reproduction in any medium, provided the original work is properly cited. 


\section{Qualidade sanitária dos rios das Comunidades do Território de Manguinhos, Rio de Janeiro, RJ}

\section{RESUMO}

Nas comunidades de Manguinhos ações de saneamento são escassas, por isso a avaliação das condições sanitárias das águas dos rios e do peridomicílio que perpassa as comunidades permite o diagnóstico do risco e da precariedade das situações de saneamento. Este estudo avaliou os níveis colimétricos (coliformes totais e Escherichia coli) pelo método de membrana filtrante, e parasitológicos (pelos métodos de Lutz e Baermann-Moraes adaptados) nas águas e no solo dos rios Faria-Timbó, Jacaré e Canal do Cunha que passam pelas comunidades do Território de Manguinhos, RJ, de acordo com os padrões estabelecidos em legislações brasileira. Em todos os pontos dos rios, a água estava imprópria com nível médio de Escherichia coli em 3.800 vezes maior do que o padrão estabelecido na Resolução CONAMA n ${ }^{\circ}$ 274/2000. Sendo observadas larvas, ovos de helmintos e oocistos de protozoários. As amostras de solo também se apresentavam impróprias, com nível médio de coliformes totais em 77.000 vezes maior do que o aceitável pela Resolução SMAC n ${ }^{\circ} 468 / 2010$, e nível de Escherichia coli em 53.000 vezes maior do que o padrão da legislação. Contudo, somente em um ponto de amostra de solo foram encontrados ovos de helmintos. Conclui-se que os reflexos da carência de saneamento nesta localidade refletem os elevados níveis colimétricos e parasitológicos das águas dos rios e no solo peridomiciliar, sendo necessária uma urgente modificação no paradigma ambiental brasileiro, que utiliza seus corpos hídricos como veículo de disposição de esgoto.

Palavras-chave: água de rio, coliformes, parasitos, qualidade sanitária, solo peridomiciliar.

\section{INTRODUCTION}

The communities of the Territory of Manguinhos are located in the Canal do Cunha subbasin that is part of the Guanabara Bay basin. The sub-basin collects water from springs that cross densely populated areas, which also contribute to the contamination of rivers through the discharge of untreated sewage and solid residues directly into water bodies (FIOCRUZ, 2015). The neighborhood of Manguinhos includes thirteen communities with 38,461 inhabitants (Brasil, 2013) which do not have an adequate sanitation system. Sewage is discarded in septic tanks built by the residents themselves, or on the streets and sidewalks or directly into nearby rivers. Serious problems result, such as river pollution, which also arise from the discharge of waste in natura from factories. Another environmental problem of this region is related to floods, which impact the streets and residences, contaminating the environment and causing the risk of human disease. This occurs because areas are below sea level, and so flood-prone, and because of unplanned habitation of low areas (FIOCRUZ, 2015).

Safety standards for bathing are set forth in the Resolution of the National Environmental Council (CONAMA) No. 274/2000 (CONAMA, 2001). However, the poorest populations are living in areas at social risk and more subject to environmental degradation (Fujimoto, 2000). In Brazil there is still no federal standards for soil quality, only specific environmental legislation (Sotero-Martins et al., 2014), such as the municipal Resolution of Rio de Janeiro (SMAC) No. 468/2010 (Rio de Janeiro, 2010). Soil and water are considered important sources for transmission of vectors that cause diseases in humans and animals. Diseases related to contaminated soil, for example, are ascaridiasis, tricuriasis, visceral and cutaneous larva migrans (Silva et al., 2009). The most water-related diseases are giardiasis, amebiasis, acute diarrheal disease (Brasil, 2015) and cryptosporidiasis (Mons et al., 2009). 
The present work reports the sanitary conditions of the Faria-Timbó, Jacaré and Canal do Cunha Rivers that pass through the communities of the Territory of Manguinhos, RJ, according to the standards established in Brazilian legislation. In order to obtain more information on this locality neglected by the city management system, it highlights the importance of the sanitary quality of soil and water in regions with a low supply of sewage, since they are environmental matrices involved in the transmission of diseases, which affect humans and animals. This study will contribute information to support the creation of national legislation on the sanitary quality of primary contact soil, considering threshold values for the presence of parasites and coliforms.

\section{MATERIALS AND METHODS}

An observational descriptive exploratory study of environmental health was carried out in 2015. Samples were collected at the upstream and downstream points of the Faria-Timbó, Jacaré and Canal do Cunha Rivers in relation to the communities of Manguinhos (Handam, 2016), and were georeferenced (GPS) according to Table 1. A map of the Communities of Manguinhos's Territory, Rio de Janeiro, RJ, with sampling points from rivers is available at: https://www.google.com/maps/d/edit?mid=zu9uU8Nlhl0Y.kOoze1i21ZOM. The points were chosen considering the contact of the residents with these environments. At each sampling point $(n=7)$ a representative sample of water and soil was collected for coliform and parasitological analyses, totaling fourteen samples.

Table 1. Collection points of the Faria-Timbó, Jacaré and Canal do Cunha Rivers and the locations and coordinates obtained by georeferencing (GPS), Rio de Janeiro, RJ.

\begin{tabular}{|c|c|c|}
\hline Points & Locations Description & Coordinates \\
\hline Point 1 & upstream of the Faria-Timbó River & $22^{\circ} 52^{\prime} 18.2^{\prime \prime} \mathrm{S}, 043^{\circ} 15^{\prime} 13.7^{\prime \prime} \mathrm{W}$ \\
\hline Point 2 & upstream of Faria-Timbó River & $22^{\circ} 52^{\prime} 41.7^{\prime \prime} \mathrm{S}, 043^{\circ} 15^{\prime} 05.9^{\prime \prime} \mathrm{W}$ \\
\hline Point 3 & downstream of the Faria-Timbó River & $22^{\circ} 52^{\prime} 51.8^{\prime \prime} \mathrm{S}, 043^{\circ} 14^{\prime} 44.6^{\prime \prime} \mathrm{W}$ \\
\hline Point 4 & upstream of the Jacaré River & $22^{\circ} 53^{\prime} 01.9^{\prime \prime} \mathrm{S}, 043^{\circ} 15^{\prime} 08.6^{\prime \prime} \mathrm{W}$ \\
\hline Point 5 & downstream of the Jacaré River & $22^{\circ} 52^{\prime} 52.5^{\prime \prime} \mathrm{S}, 043^{\circ} 14^{\prime} 46.0^{\prime \prime} \mathrm{W}$ \\
\hline Point 6 & upstream of the Canal do Cunha River & $22^{\circ} 53^{\prime} 14.2^{\prime \prime} \mathrm{S}, 043^{\circ} 14^{\prime} 45.2^{\prime \prime} \mathrm{W}$ \\
\hline Point 7 & downstream of the Canal do Cunha River & $22^{\circ} 52^{\prime} 50.6^{\prime \prime} \mathrm{S}, 043^{\circ} 14^{\prime} 28.4^{\prime \prime} \mathrm{W}$ \\
\hline
\end{tabular}

For coliform analyses, water and soil samples were collected at the river bank and transferred to sterile bottles. Within 24-h, the samples were analyzed (APHA, 2012). The soil samples were diluted in a buffer solution [1.25 ml/1 stock solution A (monopotassium phosphate $34 \mathrm{~g} / \mathrm{l}$ ) and $5.0 \mathrm{ml} / \mathrm{l}$ stock solution $\mathrm{B}$ (magnesium chloride $81 \mathrm{~g} / \mathrm{l}$ ), $\mathrm{pH} 7.5 \pm 0.25$ ] sterilized at $121^{\circ} \mathrm{C}$. After stirring the samples in the buffer solution, they remained decanted for $30 \mathrm{~min}$. Then serial dilutions of 10, 500 and 25000 times were performed on the soil samples. The water samples were serially diluted 10, 100 and 1000 times (Handam, 2016; Sotero-Martins et al., 2017).

Detection of total coliforms/Escherichia coli (E. coli) was verified using chromogenic indicator culture medium, Chromocult ${ }^{\circledR}$ Coliform Agar (Cat. No. 1,10426,0100 / 500 Merck), and the membrane filtration method (APHA, 2012). The coliform results for total coliforms (CT) and Escherichia coli (EC), were transformed from most probable number (MPN) per 100 $\mathrm{ml}$ to colony-forming unit (CFU) per $\mathrm{ml}$, based on data described by Gronewold and Wolpert (2008) (Handam, 2016; Sotero-Martins et al., 2017). Threshold values for the soil matrix were considered to be improper when it had CT and EC levels above 138.44 CFU/g and 17.54 CFU/g, respectively, and for the water matrix when EC levels were above $9.23 \mathrm{CFU} / \mathrm{ml}$.

Parasitological analysis of soil samples was performed using the adapted Lutz and Baermann-Moraes Methods (Amaral et al., 2015). After sedimentation, the supernatant discarded, and the pellet preserved in SAF (2.9 ml of acetic acid, $1.5 \mathrm{~g}$ of sodium acetate, 
$4.0 \mathrm{ml}$ of $40 \%$ formaldehyde and $92.5 \mathrm{ml}$ of distilled water). The sample was then rested for 30 minutes to allow for new sedimentation. Finally, six slides of each sample were analyzed, which contained $50 \mu \mathrm{l}$ of the bottom sediment of a falcon tube stained with lugol under a microscope with magnifications of 100 times and 400 times, the latter being used to verify the measurements of the parasites (Handam, 2016; Sotero-Martins et al., 2017). The correlation of the coliform and parasitological results in the water and soil samples of the rivers was analyzed by the correlation Pearson coefficient test for parametric and Spearman data for nonparametric data $(\mathrm{p}<0.05)$ by the program BioEstat 5.3 (Ayres et al., 2007).

\section{RESULTS AND DISCUSSION}

The bacteriological parameters analyzed for the river waters were the bacteria of the coliform group having as standard the levels described in CONAMA Resolution No. 274/2000. The indicators evaluated were total coliforms (CT), which are Gram negative bacteria which can be found in the soil and in decomposing plant matter and do not necessarily correlate with fecal origin, but are more resistant in water than pathogenic intestinal bacteria (APHA, 2012). The other parameter of greatest relevance was the levels of Escherichia coli (EC), the main indicator of fecal contamination, as it is a bacteria present in the human intestinal tract and in homoeothermic animals, described in the legislation of several countries (Sotero-Martins et al., 2014).

The results of coliform levels for river water were improper at all sampling points, according to the standards established in CONAMA Resolution No. 274/2000. The highest levels of contamination were found in the sample upstream of the Canal do Cunha River, with a level of Escherichia coli $(\mathrm{CFU} / \mathrm{ml})$ 6,575 times higher than the recommended standard for bathing, and of total coliforms with a value of $67,500 \mathrm{CFU} / \mathrm{ml}$. The lowest levels were identified at the points upstream of the Faria-Timbó River, with a level of Escherichia coli $(\mathrm{CFU} / \mathrm{ml})$ 2,900 times higher than the standard established in the legislation, and total coliforms with a value of 27,000 CFU/ml (Figure 1).

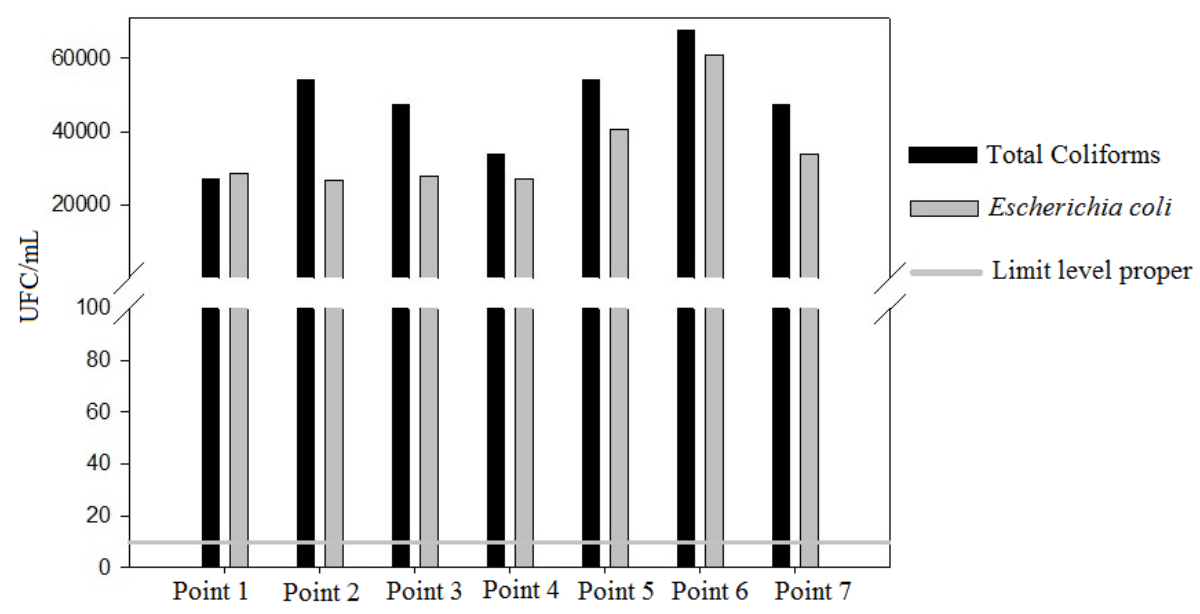

Figure 1. Total coliform and Escherichia coli levels in the water of the Faria-Timbó, Jacaré and Canal do Cunha Rivers, which pass through the Manguinhos, RJ communities. The limit values for appropriate recreational water classification are: Escherichia coli $(9,23 \mathrm{CFU} / \mathrm{ml})$, according to the Resolution of the National Environment Council - CONAMA 274/2000, considering data from the study by Gronewold e Wolpert (2008). Break interval: $100-400$. 
The average contamination by E. coli in the water of the Faria-timbó, Jacaré and Canal do Cunha Rivers was 35,029 CFU/ml, 3,800 times higher than the standard value for bathing. The mean value of contamination by total coliforms was $47,250 \mathrm{CFU} / \mathrm{ml}$. The coliform results of soil samples revealed that they were improper for primary contact, according to SMAC Resolution No 468/2010. The highest levels of contamination were found downstream of the Jacaré River, with total coliform levels of 170,639, and E. coli levels were 192,307 times greater. The lowest levels of total coliforms and $E$. coli were verified at the upstream point of the Canal do Cunha River, with total coliform levels of 469 and E. coli 3,988 times higher (Figure 2). The contamination averages found by total coliforms and by E. coli were, respectively, 77,000 and 53,000 times higher than the acceptable level for human health established by legislation.

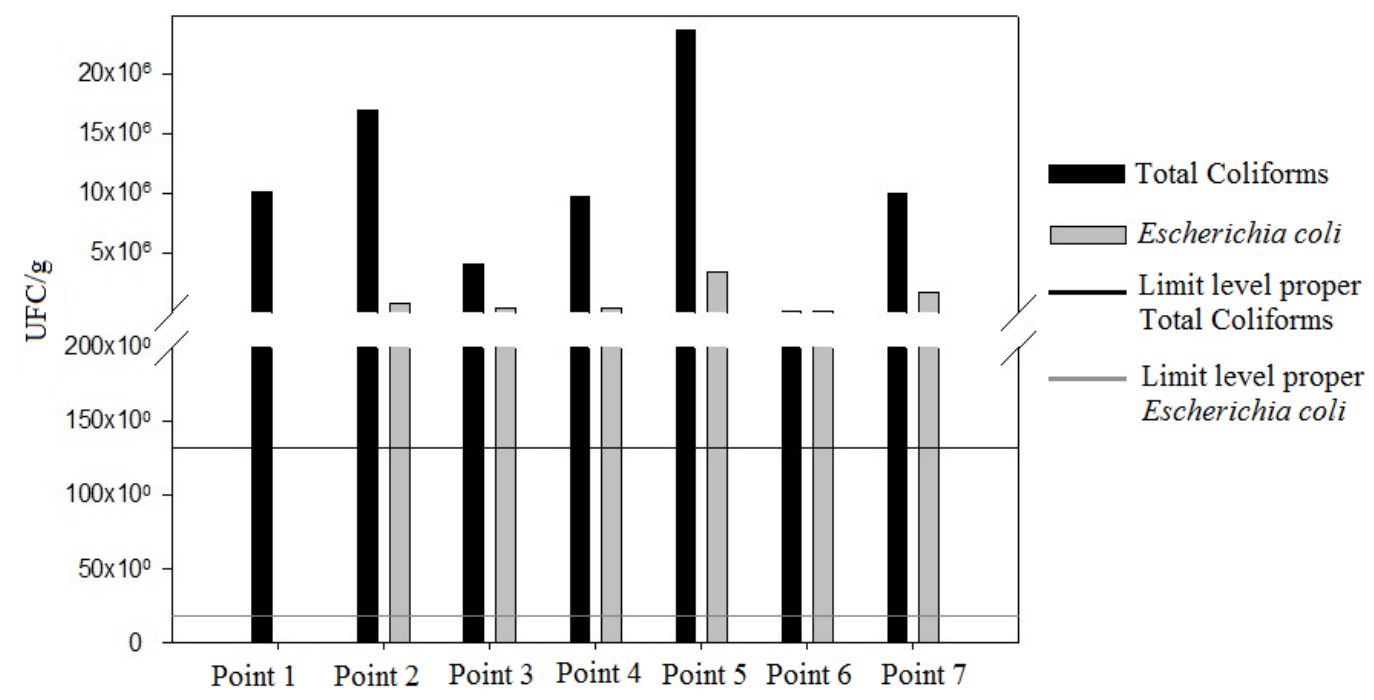

Figure 2. Total coliform and Escherichia coli levels in the soil of theFaria-Timbó, Jacaré and Canal do Cunha Rivers, which pass through the Manguinhos, RJ communities. The limit values for appropriate soil classification are: total coliforms $(138,44 \mathrm{CFU} / \mathrm{g})$, Escherichia coli $(17,54 \mathrm{CFU} / \mathrm{g})$, according to the Resolution of the Municipal Secretary of Environment - SMAC No 468/2010, considering data from the study by Gronewold and Wolpert (2008). Break interval: 200 -400 .

The levels indicated the use of water from the rivers was unfit for recreation and that the soil was unfit for primary contact without first having a disinfection process in order to eliminate the bacteria present. This contaminated water is commonly used for recreation, and comes in contact with the peridomestic soil (Gonçalves et al., 2003).

Regarding the parasitological analyses, $71 \%(5 / 7)$ of the water samples were contaminated, with the presence of 25 larvae of nematodes (filariform larvae - 20; rhabditiform larvae - 5), 15 helminth eggs and 2 protozoan oocysts detected. The downstream point of the Faria-Timbó River was the one which presented the highest parasitological contamination in comparison with the other points. The following were observed: filariform larvae (9) and rhabditiform larvae (3); egg of Toxocara sp. (1) and Ascaridata (1); oocysts of Coccidia sp. (1) and Isospora sp. (1). At the point upstream of this same river were found eggs of Ascaris sp. (1) and Strongylata (1). In the samples of the points upstream of the Faria-Timbó River and of the Jacaré River there were no parasites present. However, at the sampling point downstream of the Jacaré River eggs of Hymenolepis sp. (1), Toxocara sp. (1) and rhabditiform larvae (2) were 
found. At the point upstream of the Canal do Cunha River eggs of Ascaris sp. (2), Toxocara sp. (2), Ascaridata (1), Strongylata (2); Enterobius sp. (1); and filariform larvae (6) were found. Downstream of this river an egg of Enterobius sp. (1) and filariform larvae (5) were identified. The results of the parasitological analyses of the soil samples showed that only the sample of the upstream point of the Jacaré River presented the presence of parasites. At this point, three Ascaridata eggs with morphometric indicating Toxocara sp. (3) were found. There were loads of solid waste and human feces nearby, probably brought by the water pollution of rivers and the people who lived at this location, and there was the feces of animals that transit the environment.

It constitues a public health problem that some parasites may be transmitted by water and also by contaminated soil, since they can contaminate the water sources and peridomestic soil and due to the peculiarity of the biological cycle of its etiological agents. Also, the proximity between human and animal makes disease agents relatively important from the epidemiological point of view (Rey, 2008; Sotero-Martins et al., 2014; Amaral et al., 2016).

The statistic correlation between the results of parasites with total coliform and Escherichia coli levels found in river waters showed a positive relation, with a Pearson coefficient of 0.4948 , about $50 \%$ with a p-value of 0.2577 , and of 0.5946 , about $60 \%$ with p-value of 0.1590 , respectively (> 0.05). The correlation analysis performed with the soil samples revealed no correlation between the data. The Faria-Timbó, Jacaré and Cunha Rivers, besides receiving domestic sewage in most of their extensions, also receive industrial sewage, which causes an increase in the density of microorganisms.

The high pollution of the rivers can be reversible with the interruption of the polluting sources or the reduction of the discharge of sewage. However, it is necessary that public authorities ensure that the rivers are not used as a discharge channel. The effects of sanitary actions, or the lack thereof, greatly impact the environment, and in particular water resources (Heller and Castro, 2007).

\section{CONCLUSIONS}

The levels of coliforms found in river waters and peridomestic soil points for the communities of the Manguinhos Territory were above the limits recommended by specific legislation. In addition, parasites found in these environmental matrices demonstrate the precariousness of sanitation in this area, and coupled with the high levels of sewage contamination of the rivers places the communities of Manguinhos at risk of infections which can transmitted by water or soil. An urgent change is required in the Brazilian environmental paradigm, which uses its water bodies for sewage disposal.

\section{ACKNOWLEDGMENTS}

We thank the people from the Laboratories LITEB, LAPSA and the Laboratory of Environmental Parasitology of the Oswaldo Cruz Foundation (FIOCRUZ) by the partnership during the realization of the Masters thesis that originated this article. Thank the Vice Direction of Research of the National School of Public Health - Notice of the VPAAPS/FIOCRUZ Process 2014-2016 and PROEX/CAPES. We also thank Dr. Adriana Sotero Martins from the Department of Health and Environmental Sanitation - ENSP/FIOCRUZ for her guidance. 


\section{REFERENCES}

AMARAL, L. S.; DUARTE, A. N.; SILVA, V. L.; PINNA, L. C. L.; SOTERO-MARTINS, A. Parasitological Indicators of Contamination at Sand of Beaches and Monitoring by Traditional Methods and Immunoenzymatic Assay. Brazilian Journal of Biosystems $\begin{array}{lllll}\text { Engineering, v. } & 9, & \text { n.4, } & \text { p. } & 304-311,\end{array}$ http://dx.doi.org/10.18011/bioeng2015v9n4p304-311

AMERICAN PUBLIC HEALTH ASSOCIATION - APHA. Standard methods for examination of water and waste water. 22th ed. Washington, 2012. 1496 p.

AYRES, M.; AYRES, J. R. M.; AYRES, D. L.; SANTOS, A. A. S. BioEstat 5.3: Aplicações Estatísticas nas Áreas das Ciências Biomédicas. 5. ed. Belém: MCT; IDSM; CNPq, 2007.

BRASIL. Ministério da Saúde. ÁguaBrasil. Sistema de Avaliação da Qualidade da Água, Saúde e Saneamento. Glossário de Doenças Relacionadas à Água. 2015 Available at: http://www.aguabrasil.icict.fiocruz.br/index.php?pag=doe. Access on: 10 Feb. 2016.

BRASIL. Sistema de Informação da Saúde Básica. Caracterização do Território. Brasília, [2013]. Available at http://andromeda.ensp.fiocruz.br/teias/saudedafamilia. Access at 10 May 2014.

CONSELHO NACIONAL DE MEIO AMBIENTE - CONAMA (Brasil). Resolução n. 274, de 29 de novembro de 2000. Diário Oficial [da] União, Brasília, 25 jan. 2001, Seção 1, p. 70-71.

FUJIMOTO, N. S. V. M. A urbanização brasileira e a qualidade ambiental. In: SUERTEGARAY, D. M. A. A.; BASSO, L. A.; VERDUM, R. (Orgs.). Ambiente e lugar no urbano: a grande Porto Alegre. Porto Alegre: Ed. da Universidade, 2000. p. 267-269.

FUNDAÇÃO OSWALDO CRUZ - FIOCRUZ. Laboratório Territorial de Manguinhos. Proteção Ambiental no Bairro. Rio de Janeiro, [2015]. Available at http://www.conhecendomanguinhos.fiocruz.br/?q=ambientenatural. Access on: 20 Sep. 2015.

GONÇALVES, R. F.; JORDÃO, E. P.; SOBRINHO, P. A. Introdução. In: GONÇALVES, R. F. (Org.). Desinfecção de efluentes sanitários, remoção de organismos patogênicos e substancias nocivas. Aplicações para fins produtivos como agricultura, aquicultura e hidroponica. Rio de Janeiro: PROSAB, 2003. p. 1-26.

GRONEWOLD, A. D.; WOLPERT, R. L. Modeling the relationship between most probable number (MNP) and colony-forming unit (CFU) estimates of fecal coliform concentration. $\begin{array}{llllll}\text { Water } & \text { Research, } & \text { v. } & \text { 42, } & \text { 3327-3334, }\end{array}$ https://doi.org/10.1016/j.watres.2008.04.011

HANDAM, N. B. Condições sanitárias da água residencial, do solo peridomiciliar e dos rios das comunidades do território de Manguinhos, RJ. 2016, 140f. Dissertação (Mestrado em Saúde Pública e Meio Ambiente) - Escola Nacional de Saúde Pública Sergio Arouca, Fundação Oswaldo Cruz, Rio de Janeiro, 2016.

HELLER, L.; CASTRO, J. E. Política pública de saneamento: apontamentos teóricoconceituais. Revista Engenharia Sanitária e Ambiental, v. 12, n. 3, p. 284-295, 2007. 
MONS, C.; DUMETRE, A.; GOSSElin, S.; GALliOT, C.; MOULIN, L. Monitoring of Cryptosporidium and Giardia River contamination in Paris area. Water Research, v. 43, p. 211-217, 2009. https://doi.org/10.1016/j.watres.2008.10.024

REY, L. Parasitologia. 4. ed. In: REY, L. I - Parte Geral. Rio de Janeiro: Guanabara Koogan, 2008. p.1-25.

RIO DE JANEIRO (Cidade). Secretaria Municipal do Meio Ambiente. Resolução SMAC n. 468 de 28 de janeiro de 2010. Dispõe sobre a análise e informações das condições das areias das praias no Município do Rio de Janeiro, Brazil. Rio de Janeiro: 2010.

SILVA, P. F.; CAVALCANTI, I. M. D.; IRMÃO, J. I.; ROCHA, F. J. Common beach sand contamination due to enteroparasites on the southern coast of Pernambuco state, Brazil. Revista do Instituto de Medicina Tropical de Sao Paulo, v. 51, p. 217-218, 2009. http://dx.doi.org/10.1590/S0036-46652009000400007

SOTERO-MARTINS, A.; DUARTE, N. A.; CARVAJAL, E.; SARQUIS, M. I. M.; FERNANDES, O. C. C. Controle da qualidade microbiológica e parasitária em áreas de recreação. Revista Eletrônica Gestão \& Saúde, v. 4, p. 1075-1092, 2014.

SOTERO-MARTINS, A.; HANDAM, N. B.; MOURA, P. G.; AMARAL, L. S.; CALDAS L. V. L.; CARVAJAL, E. Methods for Sanitary Inspection of Microbiological and Parasitary Quality of Water and Sand of Recreation Areas. American Journal of Engineering Research (AJER), v. 6, n. 2, p. 56-62, 2017. 